\title{
SYNTHESIS OF $\left(\mathrm{NH}_{4}\right)_{X} \mathrm{WO}_{3}$ NANORODS BY A NOVEL HYDROTHERMAL ROUTE
}

\section{SINTEZA $\left(\mathrm{NH}_{4}\right)_{x} \mathrm{WO}_{3}$ NANOPALČK Z NOVIM HIDROTERMALNIM POSTOPKOM}

\author{
Xianguo Luo ${ }^{1}$, Shubin $\mathrm{Zhu}^{1}$, Xuhong $\mathrm{Su}^{1}$, Jianguo Huang ${ }^{1}$, Zekun Zhou ${ }^{1}$, \\ Qiongyu Zhou ${ }^{2}$, Yufeng $\mathrm{Wen}^{3}$, Ping $\mathrm{Ou}^{1 *}$ \\ 1Jiangxi University of Science and Technology, School of Materials Science and Engineering, Hongqi Ave. No. 86, \\ Ganzhou Jiangxi 341000, China \\ ${ }^{2}$ Foshan University, School of Materials Science and Energy Engineering, Jiangwan Road No. 18, Foshan Guangdong 528000, China \\ 3 Jinggangshan University, School of Mathematical Sciences and Physics, Xueyuan Road No. 28, Ji'an Jiangxi 343009, China \\ Prejem rokopisa - received: 2019-06-13; sprejem za objavo - accepted for publication: 2019-11-08
}

doi:10.17222/mit.2019.127

We report on a novel hydrothermal route for synthesizing ammonium tungsten bronze $\left(\left(\mathrm{NH}_{4}\right)_{x} \mathrm{WO}_{3}\right)$ nanorods. As-prepared $\left(\mathrm{NH}_{4}\right)_{x} \mathrm{WO}_{3}$ nanorods have an average diameter of $150 \mathrm{~nm}$ and length of $2 \mu \mathrm{m}$. These single-crystalline nanorods are hexagonal and grow along the c-axis. The formation process of the $\left(\mathrm{NH}_{4}\right)_{x} \mathrm{WO}_{3}$ nanorods is also discussed based on time-dependent experimental results.

Keywords: hydrothermal, $\left(\mathrm{NH}_{4}\right)_{x} \mathrm{WO}_{3}$, nanorod

Avtorji v pričujočem članku poročajo o novem hidrotermalnem postopku za sintezo nanopalčk amonijevega volframata $\left(\left(\mathrm{NH}_{4}\right)_{x} \mathrm{WO}_{3}\right)$. Pripravljene nanopalčke $\left(\mathrm{NH}_{4}\right)_{x} \mathrm{WO}_{3}$ so imele povprečni premer $150 \mathrm{~nm}$ in dolžino $2 \mu \mathrm{m}$. Te monokristalinične nanopalčke imajo heksagonalno strukturo in rastejo vzdolž c-osi. Potek procesa tvorbe $\left(\mathrm{NH}_{4}\right)_{x} \mathrm{WO}_{3}$ nanopalčk avtorji opisujejo na osnovi časovno odvisnih preizkusov.

Ključne besede: hidrotermalni postopek, $\left(\mathrm{NH}_{4}\right)_{x} \mathrm{WO}_{3}$, nanopalčke

\section{INTRODUCTION}

Hexagonal tungsten bronzes are a group of nonstoichiometric compounds with the general formula $\mathrm{M}_{x} \mathrm{WO}_{3}\left(\mathrm{M}=\mathrm{Cs}, \mathrm{K}, \mathrm{Na}, \mathrm{Rb}, \mathrm{NH}_{4}\right.$, etc. $)$ that consists of mixed-valence tungsten ions $\left(\mathrm{W}^{6+}\right.$ and $\left.\mathrm{W}^{5+}\right) . \mathrm{M}_{x} \mathrm{WO}_{3}$ particles have been demonstrated to exhibit excellent near-infrared (NIR) absorption properties when dispersed in a one-dimensional form due to their unique surface electronic structures and crystallographic defects. ${ }^{1-6}$ The designed growth of $\left(\mathrm{NH}_{4}\right)_{x} \mathrm{WO}_{3}$ nanorods is of great significance because they also exhibit mixed-valence tungsten ions and show NIR shielding abilities. Additionally, a substitution of alkali metal tungsten bronzes with $\left(\mathrm{NH}_{4}\right)_{x} \mathrm{WO}_{3}$ can avoid the consumption of alkali metals, especially the expensive Cs. Furthermore, owing to the open-tunnel structure and special electronic properties of $\left(\mathrm{NH}_{4}\right)_{x} \mathrm{WO}_{3}$, the mobility of the cations in the channels of the $\mathrm{WO}_{3}$ framework allows a dramatic modification of their electronic properties due to ion exchange or intercalation, giving the $\left(\mathrm{NH}_{4}\right)_{x} \mathrm{WO}_{3}$ species broad application prospects as catalytic, battery, gas sensing and electrochromic materials. $^{7}$

*Corresponding author's e-mail:

opyp@163.com (Ping Ou)
Unfortunately, due to the high structural distortion of $\left(\mathrm{NH}_{4}\right)_{x} \mathrm{WO}_{3}$ as a result of the insertion of large $\mathrm{NH}^{4+}$ ions into the $\mathrm{WO}_{6}$ octahedral framework, it is still fairly difficult to synthesize. Until now, there have been few reports on the synthesis of one-dimensional $\left(\mathrm{NH}_{4}\right)_{x} \mathrm{WO}_{3}$. S. Guo et al. ${ }^{6}$ reported a solvothemal method for preparing $\left(\mathrm{NH}_{4}\right)_{x} \mathrm{WO}_{3}$ nanorods at $200{ }^{\circ} \mathrm{C}$ for $72 \mathrm{~h}$. However, the practical applications of this process are limited by complicated procedures, long reaction times and the use of expensive and environmentally unfriendly organic solvents. Consequently, exploiting simple, mild, low-cost routes for the preparation of $\left(\mathrm{NH}_{4}\right)_{x} \mathrm{WO}_{3}$ is quite imperative and exceedingly challenging.

In this work, we propose a novel, simple hydrothermal route for synthesizing $\left(\mathrm{NH}_{4}\right)_{x} \mathrm{WO}_{3}$ nanorods at $200{ }^{\circ} \mathrm{C}$ for $12 \mathrm{~h}$, with sodium tungstate dihydrate $\left(\mathrm{Na}_{2} \mathrm{WO}_{4} \cdot 2 \mathrm{H}_{2} \mathrm{O}\right)$, thiourea $\left(\mathrm{CH}_{4} \mathrm{~N}_{2} \mathrm{~S}\right)$ and citric acid monohydrate $\left(\mathrm{C}_{6} \mathrm{H}_{8} \mathrm{O}_{7} \cdot \mathrm{H}_{2} \mathrm{O}\right)$ as the starting materials. Single-crystalline $\left(\mathrm{NH}_{4}\right)_{x} \mathrm{WO}_{3}$ nanorods were obtained under mild conditions at a low cost. The formation of the $\left(\mathrm{NH}_{4}\right)_{x} \mathrm{WO}_{3}$ nanorods is also discussed based on timedependent experiments. 


\section{EXPERIMENTAL PART}

In a typical procedure, $3.07 \mathrm{~g}$ of $\mathrm{Na}_{2} \mathrm{WO}_{4} \cdot 2 \mathrm{H}_{2} \mathrm{O}, 1.78$ $\mathrm{g}$ of $\mathrm{CH}_{4} \mathrm{~N}_{2} \mathrm{~S}$ and $1.92 \mathrm{~g}$ of $\mathrm{C}_{6} \mathrm{H}_{8} \mathrm{O}_{7} \cdot \mathrm{H}_{2} \mathrm{O}$ were dissolved in $30 \mathrm{~mL}$ of deionized water under vigorous stirring for $10 \mathrm{~min}$. The obtained mixed solution was transferred into a 50-mL stainless-steel Teflon-lined autoclave, which was filled with deionized water up to $80 \%$ of the total volume. The hydrothermal treatment was performed by placing the sealed autoclave in an oven and maintaining it at $200{ }^{\circ} \mathrm{C}$ for different reaction times. Then the autoclave was taken out and cooled to room temperature in air. The products were filtered and washed with deionized water and ethanol several times in turn, and finally oven dried in air at $60^{\circ} \mathrm{C}$ for $12 \mathrm{~h}$.

Powder X-ray diffraction (XRD) patterns of the samples were measured on a D8 advance X-ray diffractometer with high-intensity $\mathrm{Cu}-K_{\alpha}(\lambda=0.15418 \mathrm{~nm})$ radiation. The surface composition and binding energy
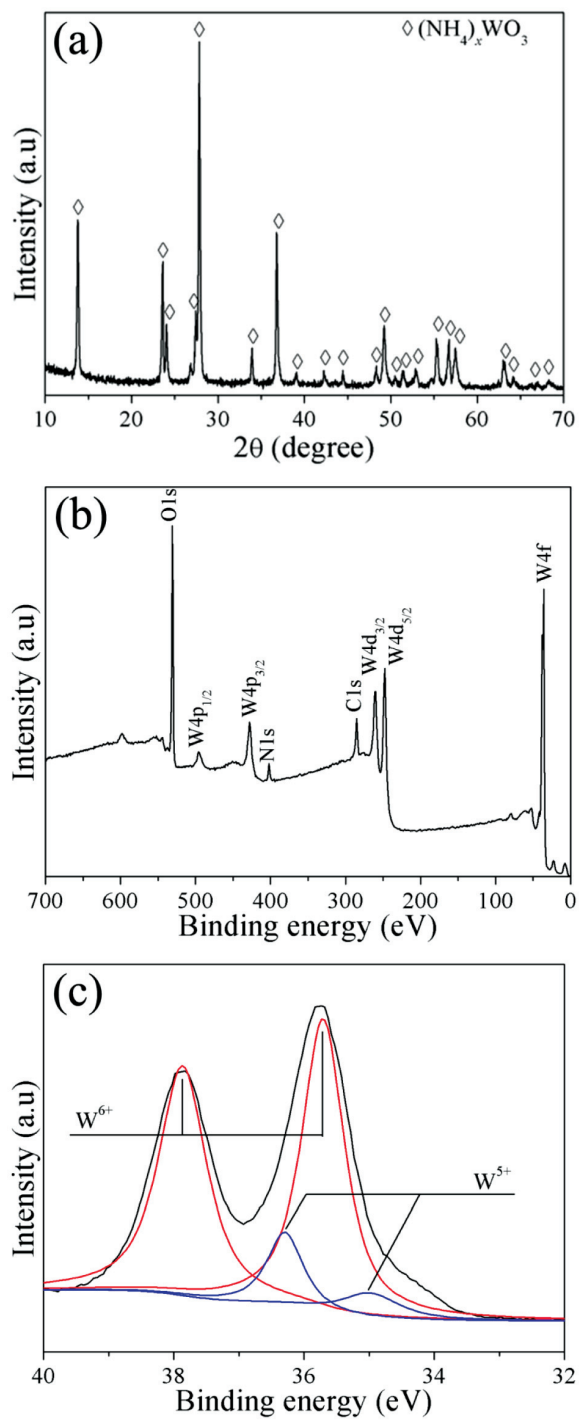

Figure 1: a) XRD pattern, b) full-range XPS spectra and c) W4f core-level XPS spectra of the as-prepared $\left(\mathrm{NH}_{4}\right)_{x} \mathrm{WO}_{3}$ sample of the samples were determined with an Esccalab 250Xi X-ray photoelectron spectrometer (XPS). Scanning-electron-microscope (SEM) images were obtained with a Zeiss iigma field-emission scanning-electron microscope. Transmission-electron-microscope (TEM) and high-resolution TEM (HRTEM) images were obtained using a FEI Tecnai G2 20 transmission electron microscope at $200 \mathrm{kV}$.

\section{RESULTS AND DISCUSSION}

Figure 1a shows the XRD pattern of the as-prepared sample hydrothermally synthesized at $200{ }^{\circ} \mathrm{C}$ for $12 \mathrm{~h}$. It was found that all the diffraction peaks could be well indexed to the hexagonal $\left(\mathrm{NH}_{4}\right)_{x} \mathrm{WO}_{3}$ with known lattice constants of $\mathrm{a}=0.7388 \mathrm{~nm}$ and $\mathrm{c}=0.7551 \mathrm{~nm}$ (ICDD PDF no. 73-1084), and no characteristic peaks for impurities such as $\mathrm{WO}_{3}$ or $\mathrm{WO}_{3-\mathrm{x}}$ were observed. The chemical composition and valence state of the as-prepared $\left(\mathrm{NH}_{4}\right)_{x} \mathrm{WO}_{3}$ sample was examined with XPS. The fully scanned spectra clearly show that $\mathrm{N}, \mathrm{W}, \mathrm{O}$ and $\mathrm{C}$ existed in the sample (Figure 1b). The presence of carbon in the final product may be related to the residual, chemically or physically adsorbed organics originating from $\mathrm{CH}_{4} \mathrm{~N}_{2} \mathrm{~S}$ or $\mathrm{C}_{6} \mathrm{H}_{8} \mathrm{O}_{7} \cdot \mathrm{H}_{2} \mathrm{O}$. The XPS peak of N1s located at $402.2 \mathrm{eV}$ may be related to the $\mathrm{NH}^{4+}$ ions in $\left(\mathrm{NH}_{4}\right)_{x} \mathrm{WO}_{3}$. For tungsten, a complex energy distribution of W4f photoelectrons was obtained, as shown in Figure 1c.

After deconvolution, the W4f core-level spectrum could be well fitted to two spin-orbit doublets, corresponding to $\mathrm{W}$ atoms in two different oxidation states. The main peaks, $\mathrm{W}_{4} \mathrm{f}_{5 / 2}$ at $37.8 \mathrm{eV}$ and $\mathrm{W}_{4} \mathrm{f}_{7 / 2}$ at $35.7 \mathrm{eV}$, could be attributed to the $\mathrm{W}$ atoms being in the $6+$ oxidation state. The second doublet, with lower binding energies of $34.9 \mathrm{eV}$ and $36.3 \mathrm{eV}$ could be assigned to the emission of the $\mathrm{W}_{4} \mathrm{f}_{5 / 2}$ and $\mathrm{W}_{4} \mathrm{f}_{7 / 2}$ core levels from the atoms in the oxidation state of 5+. These results for the core level of tungsten ions in tungsten bronze are in good agreement with reported values. ${ }^{8}$ The chemical composition determined from the deconvolution of the XPS spectrum is $\left(\mathrm{NH}_{4}\right)_{0.25} \mathrm{WO}_{3}$.

Figure 2a presents the SEM images of the as-prepared $\left(\mathrm{NH}_{4}\right)_{x} \mathrm{WO}_{3}$ sample hydrothermally synthesized at $200{ }^{\circ} \mathrm{C}$ for $12 \mathrm{~h}$. The sample consisted of numerous nanorods, which were straight and had smooth surfaces, and the average diameter and length of the nanorods were $150 \mathrm{~nm}$ and $2 \mu \mathrm{m}$, respectively. The obtained $\left(\mathrm{NH}_{4}\right)_{x} \mathrm{WO}_{3}$ nanorods were further characterized with TEM to determine their structural features and understand their crystal-growth behavior.

A low-magnification TEM image of a randomly chosen single $\left(\mathrm{NH}_{4}\right)_{x} \mathrm{WO}_{3}$ nanorod is shown in Figure 2b. The selected-area-electron-diffraction (SAED) pattern (inset in Figure 2b) of the single nanorod can be indexed to the [010] zone axis of the hexagonal $\left(\mathrm{NH}_{4}\right)_{x} \mathrm{WO}_{3}$, suggesting that the as-prepared $\left(\mathrm{NH}_{4}\right)_{x} \mathrm{WO}_{3}$ nanorods are single crystalline in nature. An HRTEM 
X. LUO et al.: SYNTHESIS OF $\left(\mathrm{NH}_{4}\right)_{X} \mathrm{WO}_{3}$ NANORODS BY A NOVEL HYDROTHERMAL ROUTE
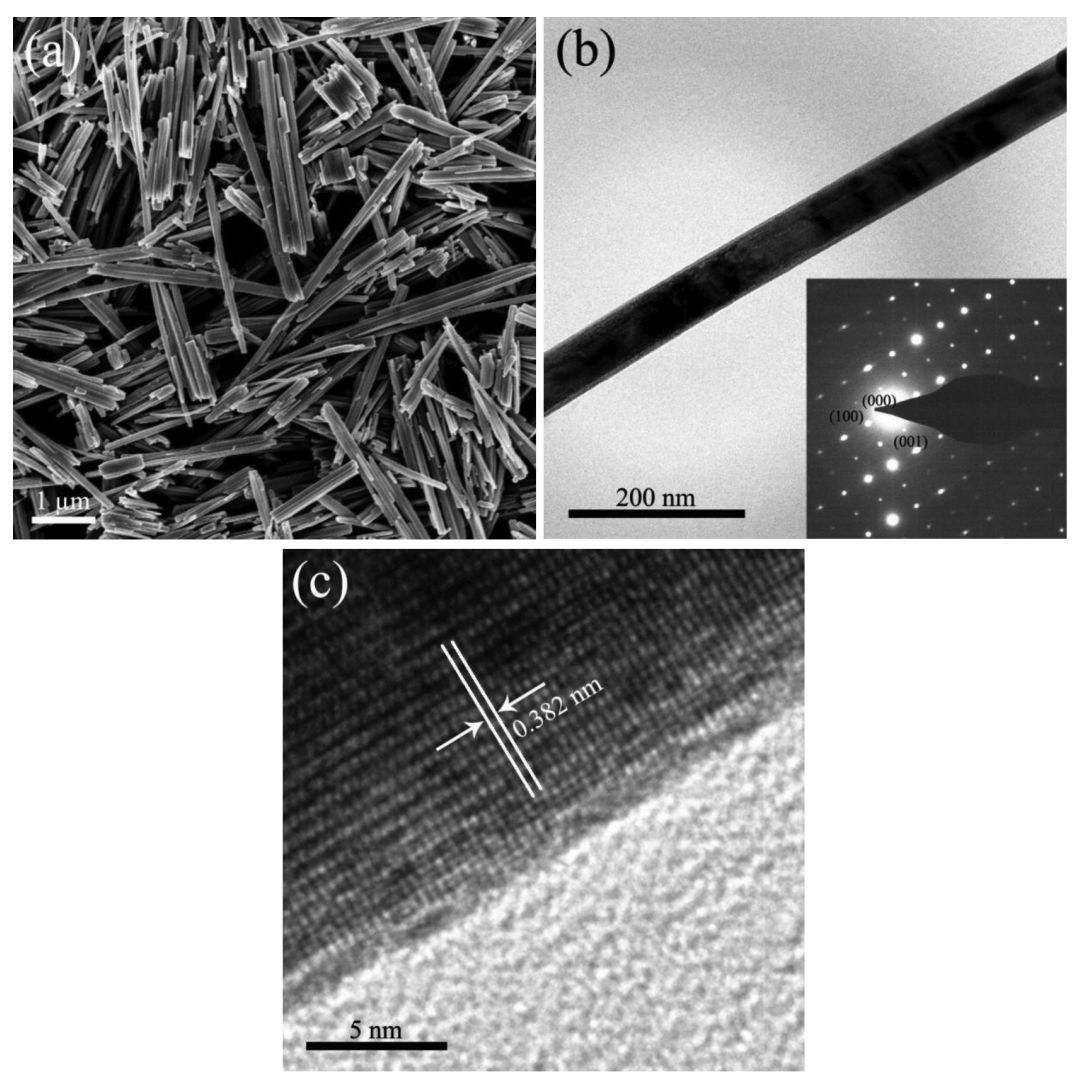

Figure 2: a) SEM image, b) TEM image and c) HRTEM image of the as-prepared $\left(\mathrm{NH}_{4}\right)_{x} \mathrm{WO}_{3}$ sample. The inset shows the corresponding SAED pattern (b)
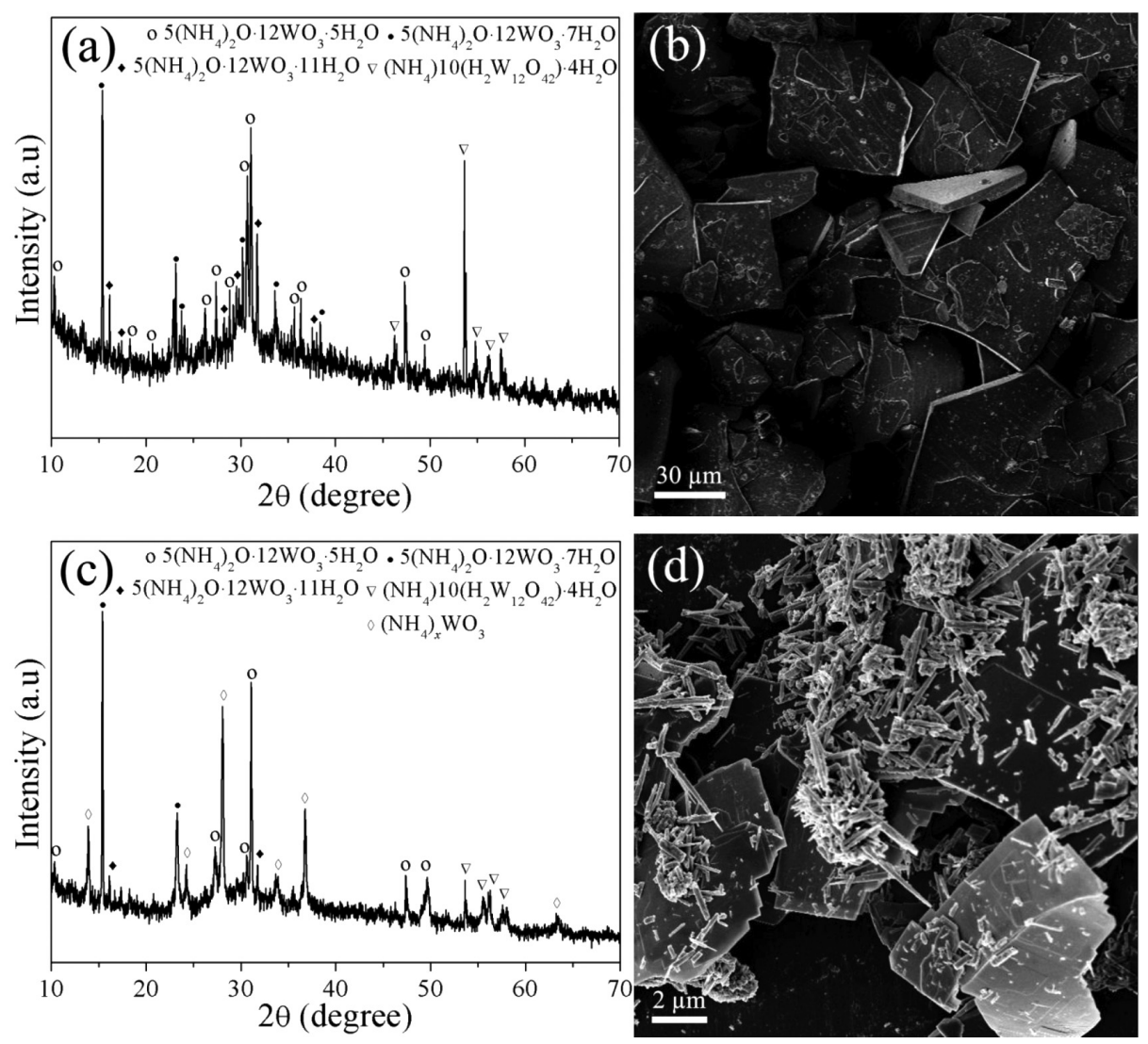

Figure 3: XRD pattern and SEM image of the products after reaction times of: $2 \mathrm{~h}(\mathrm{a}, \mathrm{b})$ and $6 \mathrm{~h}(\mathrm{c}, \mathrm{d})$, respectively 
image of the $\left(\mathrm{NH}_{4}\right)_{x} \mathrm{WO}_{3}$ nanorod at a greater magnification (Figure 2c) shows clear and ordered lattice fringes, confirming that the nanorods are single crystals. In addition, the crystalline-lattice constant in the direction parallel to the nanorod was measured as $0.382 \mathrm{~nm}$, which agrees well with the interplanar spacing of $\left(\begin{array}{lll}0 & 0 & 2\end{array}\right)$, indicating the preferential growth along the c-axis of the hexagonal bronze structure.

To understand the formation process of the singlecrystal $\left(\mathrm{NH}_{4}\right)_{x} \mathrm{WO}_{3}$ nanorods, time-dependent experiments involving changing the hydrothermal reaction time were performed. Initially, the reaction products obtained after $2 \mathrm{~h}$ of the hydrothermal treatment were identified as the $5\left(\mathrm{NH}_{4}\right)_{2} \mathrm{O} \cdot 12 \mathrm{WO}_{3} \cdot 5 \mathrm{H}_{2} \mathrm{O}$ (ICDD PDF no. 18-0128), $5\left(\mathrm{NH}_{4}\right)_{2} \mathrm{O} \cdot 12 \mathrm{WO}_{3} \cdot 7 \mathrm{H}_{2} \mathrm{O}$ (ICDD PDF no. 18-0126), $5\left(\mathrm{NH}_{4}\right)_{2} \mathrm{O} \cdot 12 \mathrm{WO}_{3} \cdot 11 \mathrm{H}_{2} \mathrm{O}$ (ICDD PDF no. 18-0127) and $\left(\mathrm{NH}_{4}\right)_{10}\left(\mathrm{H}_{2} \mathrm{~W}_{12} \mathrm{O}_{42}\right) \cdot 4 \mathrm{H}_{2} \mathrm{O}$ (ICDD PDF no. 40-1470) phases from their XRD patterns (Figure 3a). The chemical formula of these phases can be represented as $5\left(\mathrm{NH}_{4}\right)_{2} \mathrm{O} \cdot 12 \mathrm{WO}_{3} \cdot n \mathrm{H}_{2} \mathrm{O}(n=5,7,11)$. The obtained $5\left(\mathrm{NH}_{4}\right)_{2} \mathrm{O} \cdot 12 \mathrm{WO}_{3} \cdot n \mathrm{H}_{2} \mathrm{O}$ products display a sheet-like appearance with a lateral size of tens of micrometers (Figure 3b). The $5\left(\mathrm{NH}_{4}\right)_{2} \mathrm{O} \cdot 12 \mathrm{WO}_{3} \cdot n \mathrm{H}_{2} \mathrm{O}$ products were gradually converted into hexagonal $\left(\mathrm{NH}_{4}\right)_{x} \mathrm{WO}_{3}$ due to a certain amount of hexagonal $\left(\mathrm{NH}_{4}\right)_{x} \mathrm{WO}_{3}$ phase, the diffraction peaks of which were detected when the reaction time was extended to $6 \mathrm{~h}$ (Figure 3c).

The SEM image also demonstrates that the $5\left(\mathrm{NH}_{4}\right)_{2} \mathrm{O} \cdot 12 \mathrm{WO}_{3} \cdot n \mathrm{H}_{2} \mathrm{O}$ phases dissolved and that species with a rod-like appearance were formed (Figure 3d). When the reaction time was extended to $12 \mathrm{~h}$, only $\left(\mathrm{NH}_{4}\right)_{x} \mathrm{WO}_{3}$ nanorods were found in the sample (Figure 2a), and no sheet-like $5\left(\mathrm{NH}_{4}\right)_{2} \mathrm{O} \cdot 12 \mathrm{WO}_{3} \cdot n \mathrm{H}_{2} \mathrm{O}$ phases remained. In addition, as a comparative experiment, when neither $\mathrm{CH}_{4} \mathrm{~N}_{2} \mathrm{~S}$ nor $\mathrm{C}_{6} \mathrm{H}_{8} \mathrm{O}_{7} \cdot \mathrm{H}_{2} \mathrm{O}$ were used in this hydrothermal system, no $\left(\mathrm{NH}_{4}\right)_{x} \mathrm{WO}_{3}$ phases were generated even if the other experimental conditions were maintained.

Based on the above results, the suggested reaction equations in this hydrothermal system are as follows:

$$
\begin{gathered}
12 \mathrm{WO}_{4}{ }^{2-}+18 \mathrm{H}^{+} \rightarrow \mathrm{H}_{2} \mathrm{~W}_{12} \mathrm{O}_{40}{ }^{6-}+8 \mathrm{H}_{2} \mathrm{O} \\
\mathrm{CH}_{4} \mathrm{~N}_{2} \mathrm{~S}+2 \mathrm{H}_{2} \mathrm{O} \rightarrow 2 \mathrm{NH}_{3}+\mathrm{H}_{2} \mathrm{~S}+\mathrm{CO}_{2} \\
\mathrm{H}_{2} \mathrm{~W}_{12} \mathrm{O}_{40}{ }^{6-}+10 \mathrm{NH}_{3}+(n+7) \mathrm{H}_{2} \mathrm{O} \rightarrow \\
5\left(\mathrm{NH}_{4}\right)_{2} \mathrm{O} \cdot 12 \mathrm{WO}_{3} \cdot n \mathrm{H} 2 \mathrm{O}+6 \mathrm{OH}^{-} \\
5\left(\mathrm{NH}_{4}\right)_{2} \mathrm{O} \cdot 12 \mathrm{WO}_{3} \cdot n \mathrm{H}_{2} \mathrm{O}+2 x \mathrm{H}_{2} \mathrm{~S} \rightarrow 12\left(\mathrm{NH}_{4}\right)_{x} \mathrm{WO}_{3}+ \\
+(10-12 x) \mathrm{NH}_{3}+2 x \mathrm{SO}_{2}+(n+5-4 x) \mathrm{H}_{2} \mathrm{O}
\end{gathered}
$$

During the initial stage, $\mathrm{WO}_{4}{ }^{2-}$ and $\mathrm{H}^{+}$ions were released by $\mathrm{Na}_{2} \mathrm{WO}_{4} \cdot 2 \mathrm{H}_{2} \mathrm{O}$ and $\mathrm{C}_{6} \mathrm{H}_{8} \mathrm{O}_{7} \cdot \mathrm{H}_{2} \mathrm{O}$ into the solution, respectively. Then, $\mathrm{H}_{2} \mathrm{~W}_{12} \mathrm{O}_{40}{ }^{6-}$ ions were generated due to the reaction of $\mathrm{WO}_{4}{ }^{2-}$ and $\mathrm{H}^{+},{ }^{9,10}$ as shown with Equation (1). The hydrolysis of $\mathrm{CH}_{4} \mathrm{~N}_{2} \mathrm{~S}$ could produce massive quantities of $\mathrm{NH}_{3}$ and $\mathrm{H}_{2} \mathrm{~S}$ under hydrothermal conditions, as expressed with Equation (2). As the reaction time increased, the $\mathrm{H}_{2} \mathrm{~W}_{12} \mathrm{O}_{40}{ }^{6-}$ ions further reacted with $\mathrm{NH}_{3}$ and $\mathrm{H}_{2} \mathrm{O}$, forming sheet-like

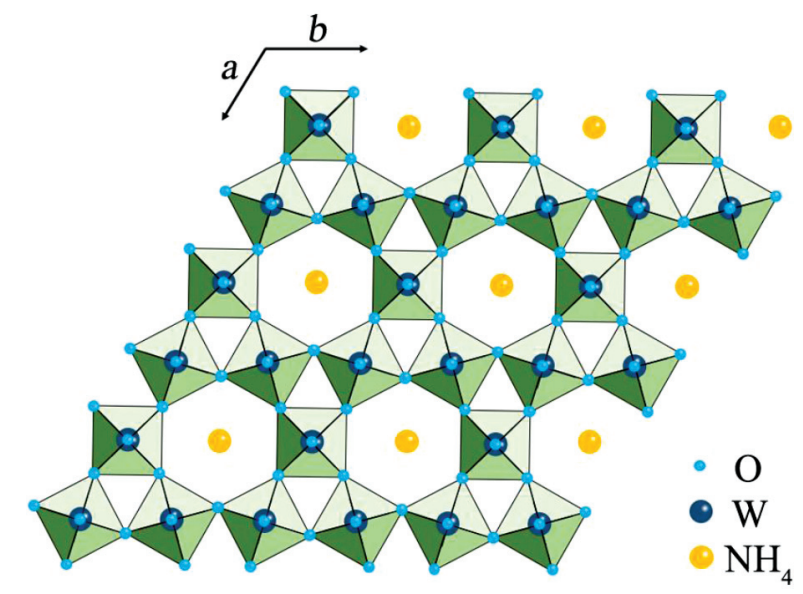

Figure 4: Crystal structure of the as-prepared $\left(\mathrm{NH}_{4}\right)_{x} \mathrm{WO}_{3}$ sample

$5\left(\mathrm{NH}_{4}\right)_{2} \mathrm{O} \cdot 12 \mathrm{WO}_{3} \cdot n \mathrm{H}_{2} \mathrm{O}$ phases according to Equation (3). As the reaction time progressed further, these sheet-like $5\left(\mathrm{NH}_{4}\right)_{2} \mathrm{O} \cdot 12 \mathrm{WO}_{3} \cdot n \mathrm{H}_{2} \mathrm{O}$ phases were gradually transformed into $\left(\mathrm{NH}_{4}\right)_{x} \mathrm{WO}_{3}$ nanorods upon an $\mathrm{H}_{2} \mathrm{~S}$ reduction through a dissolution-recrystallization mechanism. ${ }^{11,12}$ The chemical reaction of this process can be expressed with Equation (4). Finally, the pure $\left(\mathrm{NH}_{4}\right)_{x} \mathrm{WO}_{3}$ nanorods were obtained at the expense of a complete consumption of the sheet-like $5\left(\mathrm{NH}_{4}\right)_{2} \mathrm{O} \cdot 12 \mathrm{WO}_{3} \cdot n \mathrm{H}_{2} \mathrm{O}$ phases $(12 \mathrm{~h})$. The oriented growth of the $\left(\mathrm{NH}_{4}\right)_{x} \mathrm{WO}_{3}$ nanorods is associated with their specific crystal structure.

In hexagonal tungsten bronzes $\left(\mathrm{M}_{x} \mathrm{WO}_{3}, x \leq 0.33\right)$, the structure mainly comprises a rigid tungsten-oxygen framework built of layers containing corner-sharing $\mathrm{WO}_{6}$ octahedra, which are arranged in six membered rings. The layers are stacked along the c-axis, leading to the formation of one-dimensional open hexagonal channels, which are randomly occupied by cations (Figure 4). ${ }^{13}$ Therefore, the growth preferentially occurs along the c-axis of the $\left(\mathrm{NH}_{4}\right)_{x} \mathrm{WO}_{3}$ nanorods due to their specific crystal structure.

\section{CONCLUSIONS}

In summary, single-crystalline $\left(\mathrm{NH}_{4}\right)_{x} \mathrm{WO}_{3}$ nanorods with hexagonal structures were obtained through a novel hydrothermal route at $200{ }^{\circ} \mathrm{C}$, taking $12 \mathrm{~h}$, with $\mathrm{Na}_{2} \mathrm{WO}_{4} \cdot 2 \mathrm{H}_{2} \mathrm{O}, \mathrm{CH}_{4} \mathrm{~N}_{2} \mathrm{~S}$ and $\mathrm{C}_{6} \mathrm{H}_{8} \mathrm{O}_{7} \cdot \mathrm{H}_{2} \mathrm{O}$ as the starting materials. The as-prepared $\left(\mathrm{NH}_{4}\right)_{x} \mathrm{WO}_{3}$ nanorods had an average diameter of $150 \mathrm{~nm}$ and length of $2 \mu \mathrm{m}$ and they grew along the c-axis. Time-dependent experiments were carried out to further clarify the formation of the $\left(\mathrm{NH}_{4}\right)_{x} \mathrm{WO}_{3}$ nanorods. This study provides a simple, mild and economical route for preparing one-dimensional $\left(\mathrm{NH}_{4}\right)_{x} \mathrm{WO}_{3}$ nanostructures. 


\section{Acknowledgment}

This work was supported by the Doctoral Scientific Research Starting Foundation of the Jiangxi University of Science and Technology (Grant No. jxxjbs17020) and the Open Foundation of the State Key Laboratory for Advanced Metals and Materials, the University of Science and Technology of Beijing (Grant No. 2018-Z01).

\section{REFERENCES}

${ }^{1}$ C. S. Guo, S. Yin, P. L. Zhang, M. Yan, K. Adachi, T. Chonan, T. Sato, Novel synthesis of homogenous $\mathrm{Cs}_{x} \mathrm{WO}_{3}$ nanorods with excellent NIR shielding properties by a water controlled-release solvothermal process, J. Mater. Chem., 20 (2010), 8227-8229, doi:10.1039/c0jm01972k

${ }^{2}$ C. S. Guo, S. Yin, M. Yan, T. Sato, Facile synthesis of homogeneous $\mathrm{Cs}_{x} \mathrm{WO}_{3}$ nanorods with excellent low-emissivity and NIR shielding property by a water controlled-release process, J. Mater. Chem., 21 (2011), 5099-5105, doi:10.1039/c0jm04379f

${ }^{3}$ C. S. Guo, S. Yin, T. Sato, Synthesis of one-dimensional hexagonal sodium tungsten oxide and its near-infrared shielding property, Nanosci. Nanotechnol. Lett., 3 (2011), 413-416, doi:10.1166/nnl. 2011.1182

${ }^{4}$ C. S. Guo, S. Yin, L. J. Huang, T. Sato, Synthesis of one-dimensional potassium tungsten bronze with excellent near-infrared absorption property, ACS Appl. Mater. Interfaces, 3 (2011), 2794-2799, doi:10.1021/am200631e
${ }^{5}$ C. S. Guo, S. Yin, L. J. Huang, L. Yang, T. Sato, Discovery of an excellent IR absorbent with a broad working waveband: $\mathrm{Cs}_{x} \mathrm{WO}_{3}$ nanorods, Chem. Commun., 47 (2011), 8853-8855, doi:10.1039/ c1cc12711j

${ }^{6}$ C. S. Guo, S. Yin, Q. Dong, T. Sato, Simple route to $\left(\mathrm{NH}_{4}\right)_{x} \mathrm{WO}_{3}$ nanorods for near infrared absorption, Nanoscale, 4 (2012), 3394-3398, doi:10.1039/c2nr30612c

${ }^{7}$ C. S. Guo, S. Yin, T. Sato, Tungsten oxide-based nanomaterials: morphological-control, properties, and novel applications, Rev. Adv. Sci. Eng., 1 (2012), 235-263, doi:10.1166/rase.2012.1016

${ }^{8}$ M. Sun, N. Xu, Y. W. Cao, J. N. Yao, E. G. Wang, Nanocrystalline tungsten oxide thin film: preparation, microstructure, and photochromic behavior, J. Mater. Res., 15 (2000), 927-933, doi:10.1557/JMR. 2000.0132

${ }^{9}$ J. P. Launay, M. Boyer, F. Chauveau, High resolution PMR of several isopolytungstates and related compounds, J. Inorg. Nucl. Chem., 38 (1976), 243-247, doi:10.1016/0022-1902(76)80402-2

${ }^{10}$ J. J. Hastings, O. W. Howarth, A ${ }^{183} \mathrm{~W},{ }^{1} \mathrm{H}$ and ${ }^{17} \mathrm{O}$ nuclear magnetic resonance study of aqueous isopolytungstates, J. Chem. Soc. Dalton Trans., 2 (1992), 209-215, doi:10.1039/dt9920000209

${ }^{11}$ L. Q. Jiang, Y. Qiu, Z. G. Yi, Potassium niobate nanostructures: controllable morphology, growth mechanism, and photocatalytic activity, J. Mater. Chem. A, 1 (2013), 2878-2885, doi:10.1039/C2TA01056A

${ }^{12}$ X. Li, J. L. Zang, Facile hydrothermal synthesis of sodium tantalate $\left(\mathrm{NaTaO}_{3}\right)$ nanocubes and high photocatalytic properties, J. Phys. Chem. C, 113 (2009), 19411-19418, doi:10.1021/jp907334z

${ }^{13}$ A. Hussain, L. Kihlborg, A. Klug, The transformation between hexagonal potassium tungsten bronze and polytungstate, J. Solid State Chem., 25 (1978), 189-195, doi:10.1016/0022-4596(78)90102-0 